\title{
Gebelikte Sigara Kullanımının Prenatal Bağlanmaya Etkisi
}

\section{The Effect of Smoking During Pregnancy on Prenatal Attachment}

\author{
${ }^{1}$ Filiz ASLANTEKİN ÖZÇOBAN, ${ }^{2}$ Hacer YALNIZ DILLCEN, ${ }^{3}$ Serap KAYNAK, ${ }^{4}$ Nesibe UZEL \\ ${ }^{1}$ Balikesir University, Faculty of Health Sciences, Department of Midwifery, Balıkesir, Turkey \\ ${ }^{2}$ Bartin University, Faculty of Health Sciences, Department of Midwifery, Bartın, Turkey \\ ${ }^{3}$ Balikesir University, Faculty of Health Sciences, Department of Nursing, Balıkesir, Turkey \\ ${ }^{4}$ Anatolian Midwives Association, Ankara, Turkey \\ Filiz Aslantekin Özçoban: https://orcid.org/0000-0002-0402-6959 \\ Hacer Yalnız Dilcen: https://orcid.org/0000-0001-5911-7201 \\ Serap Kaynak: https://orcid.org/0000-0001-9482-5254 \\ Nesibe Uzel: https://orcid.org/0000-0001-8679-0987
}

ÖZ

Amaç: Bu çalışma gebelikte sigara kullanım durumu, sigara kullanımının prenatal bağlanma üzerine etkisinin belirlenmesi amacıyla yapılmıștır.

Materyal ve Metot: Kesitsel tipteki çalışma, 01.09.2017 ve 30.01.2018 tarihleri arasinda bir devlet hastanesinde gerçekleştirildi. Çalışma 352 gebe ile yürütüldü. Verilerin toplanmasında sosyodemografik özellikler, obstetrik öykü, sigara içme özelliklerini içeren tanımlayıcı bilgi formu, nikotin bağımlılığ lanma envanteri kullanılmıştır.

Bulgular: Gebelerin, \% 64,5'i (n=227) hiç sigara içmediklerini, \%35,5'i $(\mathrm{n}=125)$ sigara içtiğini belirtmiştir. Sigara içenlerin \%19,6's1 $(n=69)$ gebelik sırasında sigara içmeye devam etmiş ve $\% 15,9^{\prime} \mathrm{u}(\mathrm{n}=56)$ sigarayı bırakmıştır. Çalışmada, sigara içen gebelerin, içmeyen gebelere oranla daha az eğitimli, işsiz ve plansız gebeliği olduğu saptanmıştır. Sigara içen gebelerin, prenatal bağlanma düzeyleri sigara içmeyen gebelere göre anlamlı olarak daha düşüktür $(\mathrm{p}>0,05)$.

Sonuç: Sigara içmenin prenatal bağlanma üzerine etkisi saptanmıştır. Sigara içmenin zararları gebelikte anne ve bebeğe olan etkileri hakkında kadınlara danıșmanlık yapılmalıdır. Özellikle sigara içen gebeler, antenatal izlemlerde ebelik bakımı kapsamında danışmanlık hizmetleriyle sigaranın birakılması ve prenatal bağlanma konusunda desteklenmelidir.

Anahtar Kelimeler: Gebelik, prenatal bağlanma, sigara içme

\begin{abstract}
Objective: This study was conducted to determine the smoking status during pregnancy and the effect of smoking on prenatal attachment.

Materials and Methods: The cross-sectional study was carried out in a public hospital between 01.09.2017 and 30.01.2018. The study was conducted with 352 pregnant women. In collecting data, sociodemographic features, obstetric history, descriptive information form including smoking features, Fagerstrom test and prenatal attachment inventory for nicotine addiction were used.
\end{abstract}

Results: While $64.5 \% \quad(n=227)$ of pregnant women reported that they never smoked, $35.5 \%(\mathrm{n}=125)$ stated that they smoked. $19.6 \%(n=69)$ of women who smoked said that they continued smoking during pregnancy and $15.9 \%(n=56)$ quit smoking. In the study, it was found that pregnant women who smoked had less educated, unemployed and unplanned pregnancy compared to non-smoker pregnant women. Prenatal attachment levels of pregnant women who smoke were significantly lower than nonsmoking women $(\mathrm{p}>0.05)$.

Conclusions: The effect of smoking on prenatal attachment was determined. Women should be counseled about the effects of smoking on the effects of the mother and baby during pregnancy. Especially smoking pregnant women should be supported in quitting smoking and prenatal attachment with consultancy services within the scope of midwifery care during antenatal follow-ups.

Keywords: Pregnancy, prenatal attachment, smoking
Sorumlu Yazar / Corresponding Author:

Filiz Aslantekin Özçoban

Balıkesir Üniversitesi Sağlık Bilimleri Fakültesi Ebelik Bölümü,

Cağıș Yerleșkesi Balıkesir

Tel: +90 $5447696936 /$ (0266) 2440010

E-mail: aslantekinfiliz@yahoo.com
Yayın Bilgisi / Article Info:

Gönderi Tarihi/ Received: 28/02/2020

Kabul Tarihi/ Accepted: 02/07/2020

Online Yayın Tarihi/ Published: 30/09/2020

Atıf / Cited: Aslantekin Özçoban F et al. The effect of smoking during pregnancy on prenatal attachment. Online Türk Sağllk Bilimleri Dergisi 2020;5(3):444-454. doi: 10.26453/otjhs.696268 


\section{INTRODUCTION}

Smoking during pregnancy is an important public health problem which affects both maternal and fetal health. It can cause many maternal complications such as spontaneous abortus, placenta previa, ablatio placenta as well as fetal complications such as growth retardation of intrauterine, prematurity, low birth weight, stillbirth and respiratory problem. ${ }^{1}$ It was observed that smoking is common in pregnant women in Turkey and the rate of smoking in pregnancy varies between $6,8 \%-28,0 \%$ according to regional studies. ${ }^{2,3}$ Since pregnancy is a period of woman's adopting the maternal role and taking responsibility for her baby, it is important to identify smoking and the factors associated with it in pregnancy. In recent studies, many factors effecting the smoking in pregnancy as well as its relationship with prenatal attachment were determined. ${ }^{4-6}$ Prenatal attachment, which is the only relationship between mother and her unborn baby, includes woman's feelings towards the fetus, their interactions and her perception of being a mother in pregnancy, the process of developing maternal identity. İnfant internalizes it as a mind model. ${ }^{7}$ The active party in attachment relationship is the mother. The level and quality of the attachment relationship contribute to the cognitive, sensorial and physical development of the infant by forming a basis for maternal attachment in the postnatal period. ${ }^{8,9}$ It was reported that prenatal and postnatal attachment are related to each other. ${ }^{10}$ In a United Kingdom study, it was reported that risks of anxiety, mental illness, depression, discomfort from fetus and fetal abuse in women with insufficient maternal infant attachment in antenatal period had increased. ${ }^{11}$ It was emphasized in another study that if the attachment is weak, parental applications become dysfunctional, the risk of child abuse increases and this attachment's form shapes future abuse behavior of the child. ${ }^{12}$ Prenatal attachment forms the basis of the attachment experiences in life. It can be seen that education and counseling for pregnant women who have problems with their babies have positive effects and can be treated. ${ }^{13}$ Strengthening the mother's attachment with her baby, determining the factors affecting attachment behaviors are extremely important in raising healthy generations. The aim of this study is to determine the smoking status in pregnant women and the effect of effective factors on prenatal attachment.

\section{MATERIALS AND METHODS}

Study sample: This study is a descriptive research with cross-sectional design. The study was conducted between 1.09.2017 and 30.01.2018 at State Hospital. The study was approved by Balikesir University Ethics Committee on 26.07.2017 (decision no: B201/61). After obtaining written consent from the participants by the researchers, data were collected by face-to-face interview technique.

The sample of the study was determined according to sample formula of known population. Accordingly, the frequency of smoking pregnant women in Turkey is $20 \%$ and the confidence interval would be $95 \%$ and so the sampling error would be $5 \%$. The sample was calculated for 329 persons but it was carried out with 352 people to increase the working power. Pregnant women who completed the 13th week of their pregnancy and accepted to participate in the study were included in the study. Sociodemographic attributes, obstetrical history, descriptive information form which includes smoking characteristics, Fagerstrom Test For Nicotine Dependence (FTND) and Prenatal Attachment Inventory (PAI) were used in the study. The questionnaire included 8 questions regarding sociodemographic attributes, 20 questions regarding obstetrical history and 30 questions regarding factors related with smoking attributes were prepared. In order to measure their knowledge about the harms of smoking (placental disorders, growth retardation in the infant, hypertension, premature birth, stillbirth, mental retardation in the infant, behavioral disorder in the infant, learning disability in infants, influencing the development lungs, miscarriage threat), a 10-item questionnaire was created. In this questionnaire, each item was scored with 1 point and evaluation was carried out over 10 points. It is the most frequently used test for the evaluation of smoking addiction. Initially, Fagerstrom Tolerance Test was proposed by Fagerström in 1978. This test was reviewed by Heatherton et al. in 1991 and they offered FTND. Turkish version of FTND was prepared by Uysal et al. in 2004. The Turkish version was found to be moderately reliable (Cronbach alpha: 0.56). FTND consists of six questions and each question is given a different point. Addiction levels are determined with this test as; 'very low' (0-2 points), 'less' (3-4 points), 'medium' (5 points), 'high' (6-7 points) and 'very high' (8-10 points).14 Prenatal Attachment Inventory, 21-item scale developed by Muller describes the feelings and thoughts experienced by women during pregnancy and determines the levels of their 
attachment to the baby during the prenatal period. Its adaptation to Turkish was done by Yilmaz and Beji in 2013. Each item is in 4-point likert scale which can be given points between 1-4. Minimum 21 and maximum 84 points can be obtained from this questionnaire. Higher scores obtained by the pregnant woman indicates higher level of attachment. 15

Statistical Analysis: Statistical analyses were performed by using SPSS software. Significance between the groups was investigated with chisquare, smoking addiction and prenatal attachment levels were investigated using Student's t test. The relationship between smoking addiction and prenatal attachment was investigated with correlation analysis. Statistical value of $\mathrm{p}<0.05$ was considered significant.

\section{RESULTS}

Three hundred and fifty two women participated in the study, $64.5 \%(n=227)$ of them reported that they had never smoked, $35.5 \%(n=125)$ of them reported that they are smokers. Among all smokers, 19.6\% (n =69) continued to smoke during pregnancy and $15.9 \%(n=56)$ had quit smoking (Figure 1$)$.

The sociodemographic attributes of smoker and nonsmoker pregnant women were compared. It was determined that mean age of smoker pregnant women was $26.87 \pm 5.07$ years, their mean monthly income was $2.920 \pm 0.17 £$ and mean age of marriage was $22.18 \pm 4.05$ years. The same values for smoker pregnant women were $27.32 \pm 4.51$ years, $3.012 \pm 1.29 €$ and $22.10 \pm 3.59$ years, respectively (Table 1).

It has been determined that pregnant women who smoke are $12.64 \pm 5.96$ cigarettes a day before pregnancy and pregnant women who continue to smoke are $3.24 \pm 4.21$ cigarettes a day during pregnancy. It has been reported that $12.64 \pm 5.96$ of the pregnant women smoke before pregnancy, and $3.24 \pm 4.21$ of those who smoke during pregnancy. According to the Fagerström Test for Nicotine Dependence, levels of $20 \%$ of the smoker pregnant women were found to be at "high" and "very high". The mean value of PAI points of the pregnant women was $65.20 \pm 7,11$ (min.=41 max.=84). Difference between the mean values of PAI points $(\mathrm{t}=0.77 \mathrm{p}=0.021)$ of smoker $(65.16 \pm 7.94)$ and non-smoker pregnant women was found to be statistically significant $(\mathrm{P}>0.05)$ (Table 2). Prenatal attachment results of non-smoker pregnant women were higher in comparison with smoker pregnant women.
The comparison of PAI of smoker and non-smoker women in terms of variables was made. When prenatal attachment and age variable of pregnant women were compared; no difference was found in nonsmokers $(\mathrm{t}=-1.68, \mathrm{p}=0.093)$, while there was a difference in smoker pregnant women $(\mathrm{t}=-2.08$, $\mathrm{p}=0.039$ ). Prenatal attachment was found to be high in pregnant women over 30 years of age.

The comparison of pregnant woman in terms of prenatal attachment and education variable revealed that there were significant differences in both smoker $(\mathrm{t}=-3.34, \mathrm{p}=0.001)$ and non-smoker $(\mathrm{t}=-2.57$, $\mathrm{p}=0.011$ ) pregnant women. Prenatal attachment levels of high-school or higher educated pregnant women were found to be high.

When prenatal Attachment and "planning of pregnancy" variable was compared, it was determined that there were significant differences in smoker $(\mathrm{t}=2.66, \mathrm{p}=0.009)$ and nonsmoker $(\mathrm{t}=3.42, \mathrm{p}=0.001)$ pregnant women. Prenatal attachment levels of pregnant women who had planned pregnancy were high. When prenatal attachment and "knowledge about the harms of smoking" variable was compared, prenatal attachment levels of the pregnant women in both groups who had knowledge level below 5 points were high (Table 3 ).

When the smoking characteristics of women who smoked during pregnancy were compared with their mean points of PAI, no significant differences were found with the variables of "smoking status in previous pregnancy", "smoking status before pregnancy", "daily cigarette count before pregnancy", "daily cigarette count during pregnancy", "intention of quitting", "result of quitting attempt" and "FTND" (Table 4).

\section{DISCUSSION AND CONCLUSION}

In the study, the overall PAI score was found to be $65.20 \pm 7.11$ and the prenatal attachment levels of the smoker pregnant women were found to be significantly lower than non-smokers. In the studies on woman with high risk pregnancies of mean PAI score found were 56,76 $\pm 9,23$ and $61,96 \pm 9,24$, respectively. ${ }^{16,17}$ In the study of Magee et al., smoking status was found to be associated with prenatal attachment and prenatal attachment levels of smoker pregnant women were found to be lower than nonsmoker pregnant women. ${ }^{4}$ Smoker pregnant women got lower prenatal attachment point averages in the study of Bülbül et al., which they conducted on women with high risk pregnancies. ${ }^{18}$ It was indicated in the literature that prenatal attachment levels of 
smoker pregnant women were low. ${ }^{4,19,20}$ According to these studies, the fact that pregnant women who were not smoking in their pregnancy had higher levels of attachment to their babies, could be explained by these women's will to protect themselves and their babies. These results are similar to literatür findings.

It was determined that prenatal attachment levels of smoker pregnant women over 30 years of age were high. In the literature, it was given that attachment and maternal age was inversely related. ${ }^{21}$ The differences of this results and the literature can be explained by cultural and regional differences between the subjects.

In this study, it was found that prenatal attachment levels of pregnant women in both groups (smoker/ non-smoker) who had education at high school or higher levels were high. There are studies which indicated that there was inverse relation between prenatal attachment and mother's education level. ${ }^{22}$ However, there are also studies in the literature which had similar findings with this finding. ${ }^{17,23}$ This may be caused by mother's elevated knowledge about how to connect with infant, how to manage and improve this connection due to her increased ability to access information and being affected by it with increased education level.

It was found that attachment levels of non-smoker and employed pregnant women were higher that unemployed ones. In a similar manner, also found that employed pregnant women had high levels of prenatal attachment. ${ }^{5,15,17}$ It was considered in the case of unemployed women that the needs of a new family member might be a factor that increases anxiety in socioeconomic terms.

Among smoker and non-smoker pregnant women, the ones who had planned pregnancy had high levels of prenatal attachment. Abasi et al., found in their study that the planning of pregnancy had a positive effect on the attachment. ${ }^{21}$ The facts that pregnancy takes place at the time of the spouses want and feel ready about it, and their wish for their babies to take part in their lives are the important factors affecting prenatal attachment.

Prenatal Attachment levels of both smoker and nonsmoker pregnant women, who got 5 points or less from "knowledge about the harms of smoking over the infant", were high. It was considered that these pregnant women's attachment levels may be high, since they did not have information about the harms of smoking and hence, they do not concern about the risks. These women were considered to have high levels of prenatal attachment due to their lack of knowledge of the harms of smoking and hence, their lack of concern for risks caused by it. Because, the risk of fetus being in danger and the possibilities of fetus being not healthy or alive is among the most important indicators of low prenatal attachment level in pregnant women. In high-risk pregnancies, women were reported to be less willing to develop prenatal attachment to their unborn babies as a coping mechanism ${ }^{24}$. Neethu, Bhavya and Sheela reported in their study that there was a negative relationship between prenatal attachment and pregnant women being concerned. In healthy pregnancies, high prenatal attachment levels of smoker women who are not conscious about periconceptional counseling, suggests that high levels of pregnant women who did not know the harms of smoking can be caused by their lack of knowledge about the risks of it. ${ }^{25}$ However, there is a serious problem in both situations. Mothers should increase their awareness and take initiative for healthy pregnancies.

In the study, it was determined that one-third of pregnant women smoked before, about one fifth of them continued to smoking during their pregnancy but decreased daily amount of cigarette they smoked. Average PAI points of women participated in this study were high. Prenatal attachment levels of the smoker pregnant women were found to be significantly lower than non-smokers. Moreover, pregnant women who had unplanned pregnancies, had low education levels and were unemployed had low prenatal attachment levels. In the light of these findings, it can be said that smoking pregnant women in Turkey consist of low education level, unemployed women and unplanned pregnancies. That's why in these group of women levels of prenatal attachment is lower than non-smoking women. It is recommended that all health professionals, especially the midwives with primary duty in carrying out women's health and pregnancy services, should be sensitive about smoker pregnant women.

Ethics Committee Approval: Our study was approved by the Balıkesir University Non-Interventional Clinical Research Ethics Committee (Date: 26/07/2017, decision no: 201/61).

Conflict of Interest: No conflict of interest was declared by the authors.

Author Contributions: Concept- FAÖ, SK; Supervision- FAÖ, NU, SK; Materials - FAÖ, NU, SK; Data Collection and/or Processing - FAÖ, SK; Analysis and/ or Interpretation- HYD, FAÖ; Writing 
- FAÖ, HYD, SK, NU.

Peer-review: Externally peer-reviewed.

\section{REFERENCES}

1. Yang SI, Kim BJ. Prenatal particulate matter/ tobacco smoke increases infants' respiratory 1nfections: cocoa study. Allergy Asthma Immunol Res. 2015;7(6):573-582. doi:10.4168/ aair.2015.7.6.573

2. Ergin I, Hassoy H. Maternal age, education level and migration: socieconomic determinants for smoking during pregnancy in a field study from Turkey. BMC Public Health. 2010;(10):325. doi:10.1186/1471-2458-10-325

3. Tarhan P, Yilmaz T. Gebelikte sigara kullanımı ve etkileyen faktörler. Smoking during pregnancy and the effecting factors. HSP. 2016;3(3):4047. doi:10.17681/hsp.61635

4. Magee SR, Bublitz MH, Orazin C, ve ark. The relationship between maternal-fetal attachment and cigarette smoking over pregnancy. Maternal and Child Health Journal. 2014;18(1):1017-1022. doi:10.1007/s10995-013-1330-x

5. Elkin N. Levels of prenatal attachment in pregnant women and factors affecting. Sted. 2015;24: (6):230-236.

6. Massey SH, Reiss D. Maternal personality traits associated with patterns of prenatal smoking and exposure: 1mplications foretiologicand prevention research. Neurotoxicol Teratol. 2015;(53):48 -54. doi:10.1016/j.ntt.2015.11.010

7. Bowlby J. Attachment and Loss, 2nd ed. New York, NY: Published by Basic Books; 1969. http://parentalalienationresearch.com/ PDF/1969bowlby.pdf. Erişim tarihi: 24 Haziran 2020.

8. Mercer RT. Becoming a mother versus maternal role attainment. J Nurs Scholarsh 2004;36(3):226 -532 .

9. Metin A, Pasinlioğlu T. The relatıonshıp between perceived social support and prenatal attachment in pregnant women. International Refereed Journal of Gynaecology And Maternal Child Health. 2016;(05):49-66. doi:10.17367/ JACSD.2016516857

10. Figueiredo B, Costa R. Mother-to infant emotional involvement at birth. Matern Child Health J. 2009;13(4):539-549. doi:10.1007/s10995-0080312-X

11. Pollock PH, Percy A. Maternal antenatal attachment style and potential fetal abuse. Child Abuse and Neglect. 1999;3(12):1345-1357.

doi:10.1016/S0145-2134(99)00

12. Rodriguez CM, Tucker MC. Behind the cycle of violence, beyond abuse history: a brief report on the association of parental attachment to physical child abuse potential. Violence and Victims. 2011;26(2):246-256. doi:10.1891/08866708.26.2.246

13. Wedekind D, Bandelow B. Attachment style, anxiety coping, and personality-styles in withdrawn alcohol addicted inpatients. Subst Abuse Treat Prev Policy. 2013;(8):1186-1747.

14. Uysal MA, Kadakal F. Fagerström test fornicotine dependence: reliability in a Turkish sample and factor analysis. Tuberk Toraks. 2004;52 (2):115-121.

15. Yilmaz SD, Beji NK. Prenatal bağlanma envanterinin Türkçe'ye uyarlanması: güvenilirlik ve geçerlilik çalışması. Anadolu Hemşirelik ve Sağlık Bilimleri Dergisi. 2013;16(2):103-109.

16. Erkal AY, Yilmaz S. Riskli gebelerde prenatal bağlanma ve sosyal destek. Türkiye Klinikleri J Health Sci. 2016;1(3):163-169. doi:10.5336/ healthsci.2016-50668

17. Bakır N, Ölçer Z. Prenatal attachment level of high risk pregnants and factors affecting international refereed. Journal Of Gynaecology And Matenal Child Health. 2014;(01):25-37. doi:10.17367/JACSD.2014019296

18. Bülbül M, Dilbaz B. Is increased stress affecting prenatal attachment in high risk pregnancies? Journal Of Medical Practice And Review. 2018;2 (8):217- 221.

19. Massey SH, Bublitz MH, Magee SR, ve ark. Maternal-fetal attachment differentiates patterns of prenatal smoking and exposure. Addict Behav. 2015;45:51-56. doi:10.1016/ j.addbeh.2015.01.028

20. Ossa X, Bustos L. Prenatal attachment and associated factors during the third trimester of pregnancy in Temuco, Chile. Midwifery. 2012;28 (5):689-696. doi:10.1016/j.midw.2011.08.015

21. Abasi E, Tahmasebi H. Assessment on effective factors of maternal-fetal attachment in pregnant women. Life Science Journal. 2012;9(1):68-75.

22.Lindgren K. Relationships among maternal-fetal attachment, prenatal depression, and health practices in pregnancy. Research Nursing Health. 2001;24(3):203-217. doi:10.1002/nur.1023

23. Kown M, Bang KS. Relationship of prenatal stress and depression to maternal-fetal attach- 
ment and fetal growth. J. Korean Acad. Nurs.

2011;41(2):276-283. doi: 10.4040/ jkan.2011.41.2.276

24. Publications developed by Child Welfare National Resource Centers. Promoting maternal-fetal attachment with women affected by HIV and/or substance use. Research to Practice Brief. 2013. https://wwwstage.acf.hhs.gov/sites/default/files/ cb/bibliography_nrc.pdf. Erişim tarihi: 20 Haziran 2020.

25. Neethu T, Bhavya SV. Effect of fetal movement counting on prenatal attachment and maternal worries among primigravida mothers in selected hospital, Mysuru. International Journal of Nursing Education and Research. 2018;6(2):200-204. doi:10.5958/2454-2660.2018.00045.5 


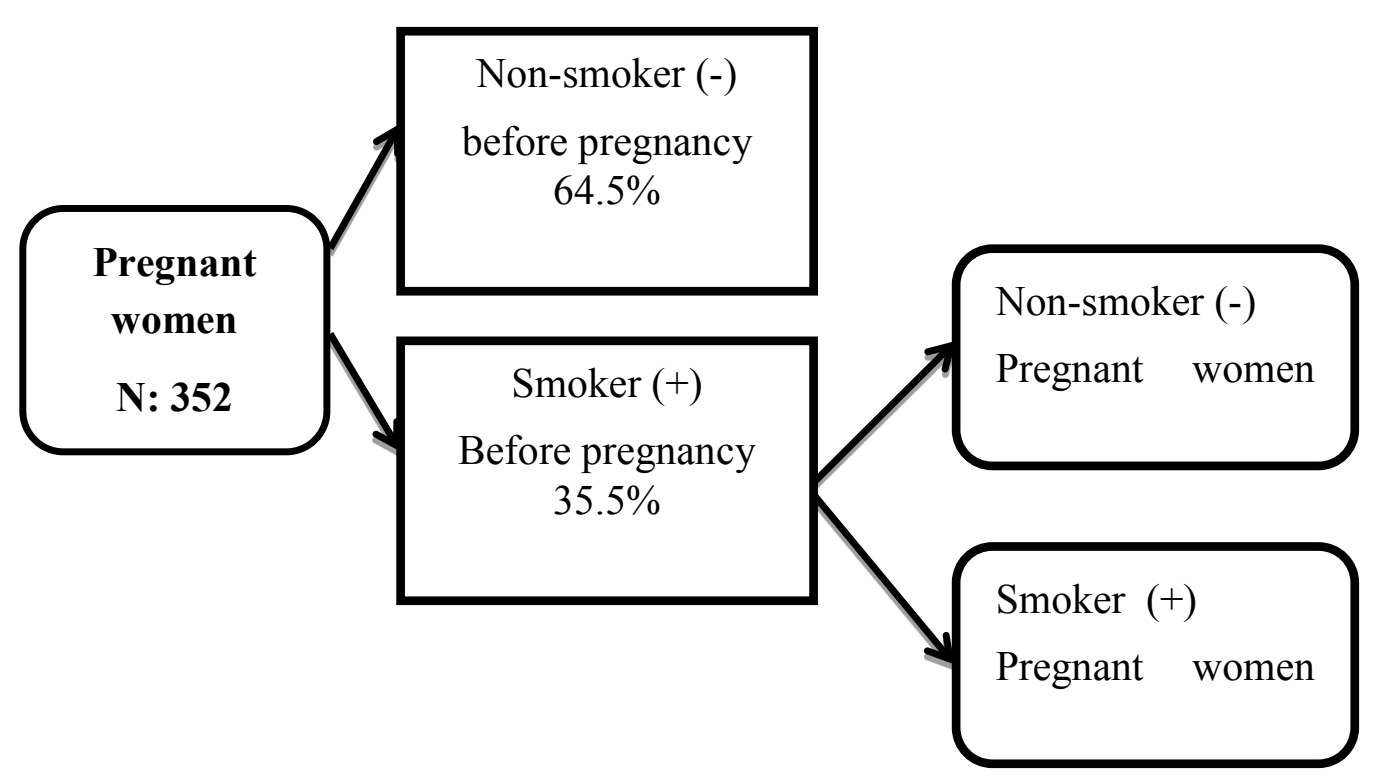

Figure 1. Smoking status of pregnant women. 
Table 1. Socio-demographic characteristics of smoker and non-smoker pregnant women.

\begin{tabular}{|l|c|c|c|c|}
\hline \multicolumn{5}{|c|}{} \\
\hline & $\begin{array}{c}\text { Non-smoker } \\
(\mathbf{n}=\mathbf{2 2 7}) \\
\text { Mean } \pm \text { SD }\end{array}$ & $\begin{array}{c}\text { Smoker } \\
(\mathbf{n}=\mathbf{1 2 5}) \\
\text { Mean } \pm \text { SD }\end{array}$ & t & p \\
\hline Age & $26.87 \pm 5.07$ & $27.32 \pm 4.51$ & -0.832 & 0.078 \\
\hline Monthly income & $2.920 \pm 0.17$ & $3.012 \pm 1.29$ & -0.313 & 0.167 \\
\hline First marriage age & $22.18 \pm 4.05$ & $22.10 \pm 3.59$ & 0.177 & 0.059 \\
\hline Number of marriages & $1.03 \pm 0.17$ & $1.04 \pm 0.23$ & -0.418 & 0.393 \\
\hline Year of the marriage & $4.50 \pm 3.00$ & $4.80 \pm 3.62$ & -0.709 & 0.521 \\
\hline First age of pregnancy & $23.47 \pm 4.60$ & $23.72 \pm 3.96$ & -0.509 & 0.081 \\
\hline Count of pregnancy & $1.79 \pm 0.95$ & $1.86 \pm 095$ & -0.710 & 0.984 \\
\hline Interval with last pregnancy & $2.56 \pm 3.94$ & $2.19 \pm 3.08$ & 0.911 & 0.152 \\
\hline
\end{tabular}


Table 2. Comparison of prenatal attachment means of smoker and non-smoker pregnant women.

\begin{tabular}{|l|c|c|c|c|}
\hline \multicolumn{5}{|c|}{ Prenatal attachment scale } \\
\cline { 1 - 3 } Smoking status & n & Mean \pm SD & t & p \\
\cline { 1 - 3 } Yes & 125 & $65.16 \pm 7.94$ & 0.07 & 0.021 \\
\cline { 1 - 3 } No & 227 & $65.22 \pm 6.63$ & & \\
\hline
\end{tabular}

$\mathrm{SD}=$ standard deviation, $\mathrm{t}=$ Independent sample $\mathrm{t}$ test, $\mathrm{p}<0.05$ 
Table 3. Comparison of prenatal attachment inventory in smoker and non-smoker pregnant women in terms of variables.

\begin{tabular}{|c|c|c|c|c|c|c|c|c|}
\hline \multicolumn{9}{|c|}{ Prenatal Attachment Scale } \\
\hline & \multicolumn{4}{|c|}{ Non-Smoker } & \multicolumn{4}{|c|}{ Smoker } \\
\hline & $\mathbf{n}$ & Mean \pm SD & & $\mathbf{p}$ & $\mathbf{n}$ & Mean \pm SD & & $\mathbf{p}$ \\
\hline \multicolumn{9}{|l|}{ Age } \\
\hline $\begin{array}{l}30 \text { and below } \\
\text { Over } 30\end{array}$ & $\begin{array}{l}65 \\
162\end{array}$ & $\begin{array}{l}64.06 \pm 6.83 \\
65.69 \pm 6.51\end{array}$ & $-1.68^{*}$ & 0.093 & $\begin{array}{l}35 \\
90\end{array}$ & $\begin{array}{l}62.82 \pm 8.90 \\
66.07 \pm 7.38\end{array}$ & $-2.08^{*}$ & $\mathbf{0 . 0 3 9}$ \\
\hline \multicolumn{9}{|l|}{ Educational status } \\
\hline $\begin{array}{l}\text { Elementary school } \\
\text { High school and over }\end{array}$ & $\begin{array}{l}74 \\
153\end{array}$ & $\begin{array}{l}63.62 \pm 7.76 \\
66.00 \pm 5.88\end{array}$ & $\begin{array}{l}- \\
2.57 * *\end{array}$ & 0.011 & $\begin{array}{l}22 \\
103\end{array}$ & $\begin{array}{l}60.22 \pm 8.71 \\
66.22 \pm 7.38\end{array}$ & $-3.34 * *$ & 0.001 \\
\hline \multicolumn{9}{|l|}{ Working status } \\
\hline $\begin{array}{l}\text { Yes } \\
\text { No }\end{array}$ & $\begin{array}{l}56 \\
171\end{array}$ & $\begin{array}{l}67.08 \pm 5.77 \\
64.61 \pm 6.79\end{array}$ & $2.44 *$ & 0.015 & $\begin{array}{l}62 \\
63\end{array}$ & $\begin{array}{l}65.90 \pm 8.28 \\
64.44 \pm 7.57\end{array}$ & $1.02 *$ & 0.306 \\
\hline \multicolumn{9}{|l|}{ Years of Marriage } \\
\hline $\begin{array}{l}5 \text { years and below } \\
\text { Over } 5 \text { years }\end{array}$ & $\begin{array}{l}82 \\
145\end{array}$ & $\begin{array}{l}63.82 \pm 7.36 \\
66.02 \pm 6.06\end{array}$ & $-2.41 *$ & 0.016 & $\begin{array}{l}47 \\
78\end{array}$ & $\begin{array}{l}62.74 \pm \\
10.10 \\
66.62 \pm 5.89 \\
\end{array}$ & $-2.71 *$ & $\mathbf{0 . 0 0 8}$ \\
\hline \multicolumn{9}{|l|}{ Planned pregnancy } \\
\hline $\begin{array}{l}\text { Yes } \\
\text { No }\end{array}$ & $\begin{array}{l}190 \\
37\end{array}$ & $\begin{array}{l}65.67 \pm 5.98 \\
61.89 \pm 8.63\end{array}$ & $-3.42 *$ & 0.001 & $\begin{array}{l}24 \\
101\end{array}$ & $\begin{array}{l}66.06 \pm 9.23 \\
61.37 \pm 9.23\end{array}$ & $-2.66^{*}$ & 0.009 \\
\hline \multicolumn{9}{|l|}{ Prenatal care } \\
\hline $\begin{array}{l}\text { Yes } \\
\text { No }\end{array}$ & $\begin{array}{l}222 \\
5\end{array}$ & $\begin{array}{l}65.13 \pm 6.59 \\
69.20 \pm 7.99\end{array}$ & $1.356^{*}$ & 0.176 & $\begin{array}{l}5 \\
120\end{array}$ & $\begin{array}{l}62.20 \pm \\
11.43 \\
65.29 \pm 7.80 \\
\end{array}$ & $-0.85^{*}$ & 0.396 \\
\hline \multicolumn{9}{|c|}{ Preconceptional folic acid usage } \\
\hline $\begin{array}{l}\text { Yes } \\
\text { No }\end{array}$ & $\begin{array}{l}147 \\
80\end{array}$ & $\begin{array}{ll}66.27 & \pm \\
5.83 & \\
63.31 & \pm \\
7.55 & \\
\end{array}$ & $-3.280^{*}$ & 0.001 & $\begin{array}{l}40 \\
85\end{array}$ & $\begin{array}{l}62.10 \pm 9.02 \\
66.61 \pm 6.97\end{array}$ & $-3.06^{*}$ & 0.003 \\
\hline \multicolumn{9}{|l|}{ Does spouse smoke? } \\
\hline $\begin{array}{l}\text { Yes } \\
\text { No }\end{array}$ & $\begin{array}{l}130 \\
77\end{array}$ & $\begin{array}{ll}64.36 & \pm \\
6.49 & \\
66.39 & \pm \\
6.67 & \\
\end{array}$ & $0.823 *$ & 0.411 & $\begin{array}{l}102 \\
23\end{array}$ & $\begin{array}{l}65.10 \pm 7.75 \\
65.43 \pm 8.90\end{array}$ & $0.17 *$ & 0.856 \\
\hline \multicolumn{9}{|c|}{ Total points of knowledge about the harms of smoking over the infant } \\
\hline $\begin{array}{l}\text { Below } 5 \text { points } \\
5 \text { points and over }\end{array}$ & $\begin{array}{l}122 \\
105\end{array}$ & $\begin{array}{ll}66.32 & \pm \\
5.16 & \\
63.95 & \pm \\
7.84 & \\
\end{array}$ & $2.727^{*}$ & $\mathbf{0 . 0 0 7}$ & $\begin{array}{l}81 \\
84\end{array}$ & $\begin{array}{l}66.41 \pm 6.68 \\
62.84 \pm 9.50\end{array}$ & $2.43 *$ & 0.016 \\
\hline
\end{tabular}

$\mathrm{SD}=$ standard deviation, $*$ Independent sample t test, $* *$ ANOVA testi, $\mathrm{p}<0.05$ 
Table 4. Comparison of prenatal attachment inventory and smoking characteristics of smoker pregnant women.

\begin{tabular}{|c|c|c|c|c|}
\hline & $\mathbf{n}$ & Mean \pm SD & & $\mathbf{p}$ \\
\hline $\begin{array}{l}\text { Smoking status in previous pregnancy } \\
\text { Yes } \\
\text { No }\end{array}$ & $\begin{array}{l}50 \\
57\end{array}$ & $\begin{array}{l}63.68 \pm 8.12 \\
66.12 \pm 8.10\end{array}$ & $1.55^{*}$ & 0.122 \\
\hline $\begin{array}{l}\text { Smoking status before pregnancy } \\
\text { Yes } \\
\text { No }\end{array}$ & $\begin{array}{c}7 \\
118 \\
\end{array}$ & $\begin{array}{c}62.14 \pm 11.39 \\
65.34 \pm 7.71 \\
\end{array}$ & $1.03 *$ & 0.301 \\
\hline $\begin{array}{l}\text { Daily cigarette counts before pregnancy } \\
\text { Below } 15 \\
\text { Over } 15\end{array}$ & $\begin{array}{l}55 \\
70 \\
\end{array}$ & $\begin{array}{l}64.65 \pm 8.27 \\
65.57 \pm 7.70 \\
\end{array}$ & $-0.63 *$ & 0.524 \\
\hline $\begin{array}{l}\text { Daily cigarette counts during pregnancy } \\
\text { Below } 10 \\
\text { Over } 10\end{array}$ & $\begin{array}{c}14 \\
114\end{array}$ & $\begin{array}{c}61.50 \pm 11.23 \\
65.63 \pm 7.36\end{array}$ & $-1.34 *$ & 0.201 \\
\hline $\begin{array}{l}\text { Intention of quitting } \\
\text { Yes } \\
\text { No }\end{array}$ & $\begin{array}{l}94 \\
31 \\
\end{array}$ & $\begin{array}{l}65.23 \pm 8.48 \\
64.96 \pm 7.79 \\
\end{array}$ & $0.161^{*}$ & 0.872 \\
\hline $\begin{array}{l}\text { Result of quitting attempt } \\
\text { I quit } \\
\text { I couldn't quit }\end{array}$ & $\begin{array}{l}65 \\
32 \\
\end{array}$ & $\begin{array}{l}66.13 \pm 7.79 \\
64.25 \pm 6.90 \\
\end{array}$ & $1.16^{*}$ & 0.248 \\
\hline \multicolumn{3}{|c|}{ Result of Fagerström Test for Nicotine Dependence } & \multirow{6}{*}{$0.291 * *$} & \multirow{6}{*}{0.883} \\
\hline Very low & 55 & $64,65 \pm 7,481$ & & \\
\hline Less & 22 & $65,22 \pm 8,766$ & & \\
\hline Medium & 23 & $66,52 \pm 5,333$ & & \\
\hline High & 19 & $65,47 \pm 10,447$ & & \\
\hline Very high & 6 & $63,50 \pm 10.153$ & & \\
\hline
\end{tabular}

$\mathrm{SD}=$ standard deviation, $*$ Independent sample t test, $* *$ ANOVA testi, $\mathrm{p}<0.05$. 